\title{
Influence of special surveillance programmes and AIDS on declining incidence of syphilis in Amsterdam
}

\author{
R A COUTINHO, F J SCHOONHOVEN, J A R VAN DEN HOEK, AND J A EMSBROEK \\ From the Municipal Health Service, Amsterdam, the Netherlands
}

SUMMARY In 1976-8 the incidence of syphilis in Amsterdam doubled from 41 to 88 per 100000 . Contact tracers identified two major risk groups, homosexual men with multiple partners and prostitutes using drugs, and special surveillance programmes for these groups have been organised on a regular basis since 1979. As a result of these two programmes the incidence of syphilis started to decline appreciably in 1981-3. From 1984 onwards a further decline occurred in men as a result of a change of lifestyle by homosexual men, probably because of the appearance of AIDS. In 1985 the incidence of syphilis in Amsterdam had dropped to 30 per 100000 , the lowest level since notification started.

\section{Introduction}

In the second half of the 1970s the number of reported cases of early infectious syphilis in Amsterdam increased considerably: in 1976307 cases were notified, and in 1978 this had doubled to 641 . The incidence per 100000 inhabitants rose from 41 in 1976 to 88 in 1978 . Contact tracers at the sexually transmitted disease (STD) clinics of the municipal health service identified two major groups at risk of acquiring syphilis: homosexual men with multiple partners and prostitutes using hard drugs. Pilot studies among these two groups in $1978^{1}$ and $1979^{2}$ confirmed these observations. Special surveillance programmes have been organised for both groups on a regular basis since 1979.

We report here what influence these two programmes had on the incidence of syphilis in Amsterdam. We also assessed when the lifestyles of homosexual men began to change in response to an awareness of AIDS, and how this further influenced the incidence of syphilis.

\section{OUTREACHING SURVEILLANCE PROGRAMMES \\ Homosexual men}

A pilot study of homosexual men was performed in $1979 .{ }^{2}$ During one week in August a contact tracer collected blood samples from visitors to day and night

Address for reprints: Dr R A Coutinho, Municipal Health Service, PO Box 20244, 1000 HE Amsterdam, the Netherlands

Accepted for publication 27 September 1986. saunas in Amsterdam where homosexual men meet and can have sexual intercourse. Of the 318 homosexual men tested, $35 \%$ (112) had positive results to serological tests for syphilis. A regular screening programme for homosexual men started in several bars and saunas in Amsterdam in November 1979. Table I shows the results of this programme (those for the first 18 months have been described previously ${ }^{3}$ ). Only partial results were available for 1981 , and the data for that year are therefore not shown. In 1980, 66 men with untreated syphilis were detected by this programme, and since then the number has decreased slowly both absolutely and as a percentage of blood samples taken. The number of samples taken also slowly decreased because fewer screening sessions were held and the number of visitors to the bars and saunas who wanted to participate in the sessions decreased.

TABLE I Results of serological screening programme for syphilis in homosexual men in bars and saunas in Amsterdam, 1980-5 (start of programme November 1979)

\begin{tabular}{lll}
\hline Year & $\begin{array}{l}\text { No of blood } \\
\text { samples taken }\end{array}$ & $\begin{array}{l}\text { No (\%) showing } \\
\text { untreated syphilis }\end{array}$ \\
\hline 1980 & 1640 & $66(4 \cdot 0)$ \\
$*$ & & \\
1982 & 886 & $32(3 \cdot 6)$ \\
1983 & 436 & $12(2 \cdot 8)$ \\
1984 & 467 & $10(2 \cdot 1)$ \\
1985 & 274 & $5(1 \cdot 8)$ \\
\hline
\end{tabular}

*Data for 1981 incomplete therefore not shown. 
TABLE II General characteristics of people using hard drugs who attended special weekly STD clinic in Amsterdam, 1981-5

\begin{tabular}{|c|c|c|c|c|c|}
\hline \multirow[b]{2}{*}{ Variable } & \multicolumn{5}{|c|}{ No (\%) attending once or more in: } \\
\hline & $\begin{array}{l}1981 \\
(n=280)\end{array}$ & $\begin{array}{l}1982 \\
(n=217)\end{array}$ & $\begin{array}{l}1983 \\
(n=225)\end{array}$ & $\begin{array}{l}1984 \\
(n=258)\end{array}$ & $\begin{array}{l}1985 \\
(n=264)\end{array}$ \\
\hline $\begin{array}{l}\text { Woman } \\
\text { Dutch } \\
\text { Prostitute } \\
\text { Aged 20-30 }\end{array}$ & $\begin{array}{l}202(72) \\
137(49) \\
230(82) \\
213(76)\end{array}$ & $\begin{array}{r}187(86) \\
87(40) \\
202(93) \\
165(76)\end{array}$ & $\begin{array}{l}187(83) \\
108(48) \\
189(84) \\
158(70)\end{array}$ & $\begin{array}{r}212(82) \\
98(38) \\
237(92) \\
196(76)\end{array}$ & $\begin{array}{l}227(86) \\
114(43) \\
243(92) \\
190(72)\end{array}$ \\
\hline
\end{tabular}

STD $=$ sexually transmitted disease.

\section{Prostitutes using hard drugs}

A pilot study of prostitutes using drugs was performed in the summer of $1978 .{ }^{1}$ Contact tracers went to the area where the prostitutes worked and persuaded some of them to come to the nearby STD clinic for examination.In six evenings (using a mobile clinic on one evening) 48 prostitutes were examined, and nine cases of early infectious syphilis were detected in 41 women.In April 1979 a regular STD clinic for prostitutes using drugs started on one evening a week From September 1979 the drug abuse department of the Municipal Health Service also participated in this programme. Methadone was offered as a substitute for heroin, especially if an STD was detected, so that the prostitutes would stop working for a while. Routine medical and laboratory examinations for STDs were performed at the clinic. Most of the visitors were female prostitutes aged 20 to 30 , and an increasing number came from other countries, especially Germany (table II). The number of visitors an evening varied between five and 15, and most people came several times a year.

Apart from other STDs, syphilis was regularly detected in the prostitutes using drugs (especially in the women) (table III). Of the 169 visitors 29 were found to have syphilis during the first year of the programme (April 1979 to April 1980), 14 in 1983, and six in 1985. The importance of these prostitutes in the spread of syphilis and other STDs becomes clear when one realises that they have five to 10 different clients a day to pay for their (and sometimes also for their regular sexual partner's) drugs.

\section{Patients and methods}

\section{STUDY GROUP}

At each session in the bars and saunas two contact tracers were present, informed the homosexual men of the nature of the programme, and invited them to participate. Blood samples were collected by venepuncture, and basic demographic data were noted.
Men with serological findings suggestive of recent syphilis were contacted by letter and advised to see a doctor. Permission was asked to discuss their diagnosis and treatment with their doctors.

At the clinic for prostitutes using drugs a thorough medical examination for the presence of STDs was performed under the supervision of a doctor, and specimens for direct microscopy and culture were collected .During each evening one doctor, two contact tracers , one or two nurses, and a laboratory technician from our STD department were present and also one doctor and one to three public health nurses from the drug abuse department.

\section{SEROLOGICAL TESTS FOR SYPHILIS}

The serological tests used were the Venereal Disease Research Laboratory (VDRL) slide test, the Treponema pallidum haemagglutination assay (TPHA), and, for confirmation, the fluorescent treponemal antibody-absorbed (FTA-ABS) test. All these tests were performed at the Public Health Laboratory of the Municipal Health Service.

DATA ON INCIDENCE AND STATISTICAL METHODS USED

Early infectious syphilis and latent (for less than one year) syphilis have been anonymously notifiable in the Netherlands since 1976. Cases are reported by the treating doctor or by contact tracers at STD clinics . Criteria for notification have not changed since 1976.

Data about incidence were obtained from the health inspection at Leidschendam (Dr H Bijkerk). The test for trend in a $2 \times \mathrm{k}$ table was applied.

\section{Results}

The incidence of early infectious syphilis per 100000 inhabitants of Amsterdam reached a peak in 1979(98)

TABLE III New cases of syphilis detected in people using hard drugs who attended special weekly STD clinic in Amsterdam, 1979-85

\begin{tabular}{|c|c|c|c|c|c|}
\hline \multirow[b]{2}{*}{ Year } & \multicolumn{3}{|c|}{ No of attenders } & \multicolumn{2}{|c|}{ No (\%) of new cases in } \\
\hline & Total & Men & Women & Men & Women \\
\hline $1979-80^{*}$ & 169 & 62 & 107 & $6(10)$ & $23(22)$ \\
\hline 1981 & 280 & 78 & 202 & $6(8)$ & 15 (7) \\
\hline i 982 & 217 & 30 & 187 & 1 (3) & $10(5)$ \\
\hline 1983 & 225 & 38 & 187 & 1 (3) & $13(7)$ \\
\hline 1984 & 258 & 46 & 212 & 1 (2) & 3 (1) \\
\hline 1985 & 264 & 37 & 227 & $2(5)$ & 4 (2) \\
\hline
\end{tabular}

STD = sexually transmitted disease .

*April 1979 to April 1980. 


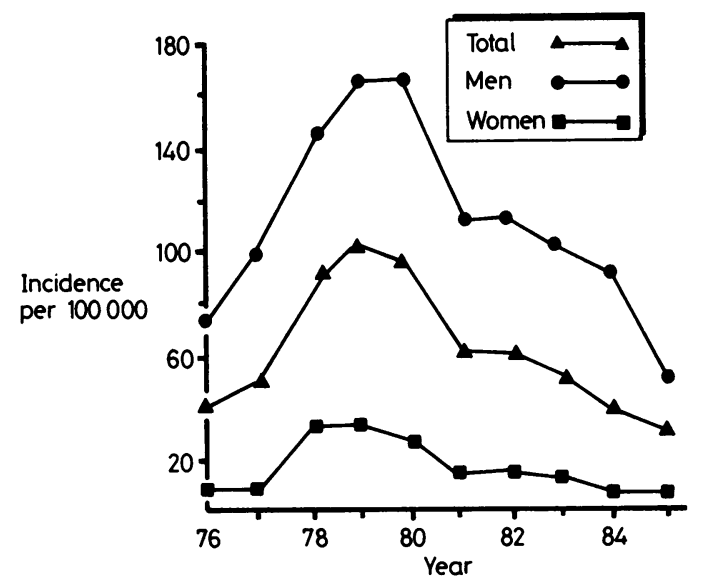

FIGURE Reported incidence of early infections syphilis in Amsterdam, 1976-85

and 1980 (96). From then on the incidence declined from 61 per 100000 in 1981 to 30 in 1985 (figure). This decline occurred in both men and women, and was significant when the years $1978-80$ and 1981-83 are compared (trend test for men: $T=-1.90, p$ (one sided) $=0.03$ ); trend test for women: $\mathrm{T}=-2 \cdot 19, \mathrm{p}$ (one sided) $=0.01$ ).

As it is known that the emergence of AIDS has influenced the lifestyle of homosexual men, we also assessed when such an influence began in Amsterdam. The first case of AIDS in the Netherlands was diagnosed in 1982, but widespread publicity did not start until 1983. From the data from our STD clinics (table IV), however, the change of lifestyle among homosexual men, only began in 1984. In 1982 and $198316 \%(502 / 3139$ and $471 / 2837)$ of the men diagnosed as having gonorrhoea at our clinics had rectal gonorrhoea, and in 36\% (1137 and 1013) it had been homosexually acquired. In 1984 these percentages dropped to $11 \%(271 / 2380)$ and $24 \%(570)$ respectively, and in 1985 a further decrease was seen.

\section{Discussion}

From 1976 to 1978 the incidence of syphilis in Amsterdam doubled and, as the contact tracers at the STD clinics had identified two major risk groups, special surveillance programmes for these groups were organised. Evaluation of the first 18 months of the programme for homosexual men showed that the cost of identifying each patient with untreated syphilis was quite low and that the rate of previously undetected syphilis declined slowly during the programme. ${ }^{3}$ This programme was therefore continued, but because the interval between the screening sessions increased the number of blood samples taken each year decreased.

The second programme, for prostitutes using drugs, was not only aimed at detecting syphilis in this group, but also other STDs. During the programme it became apparent that this group of prostitutes also played a very important part in the spread of penicillinase producing gonococci in Amsterdam. ${ }^{4}$

These two surveillance programmes had an appreciable influence on the decline of the incidence of syphilis in Amsterdam, but only to a certain level, which was reached in 1981. After that year the incidence did not decrease further until 1984, and this second decline was probably caused by the appearance of AIDS, which influenced the lifestyle of homosexual men. The human immunodeficiency virus (HIV) is transmitted between homosexual men, especially by passive anal intercourse with multiple partners. ${ }^{5}$ When homosexual men realised this (from 1984 onwards), they began to change their sexual behaviour in Amsterdam as in other cities, such as San Francisco and New York. ${ }^{6}$ As syphilis in homosexual men is probably transmitted mainly by passive anal intercourse, the change in sexual behaviour also influenced the incidence of syphilis.

To exclude other (unknown) influences on the incidence of syphilis, we also compared the data from Amsterdam with those from Rotterdam, the only city of comparable size in the Netherlands. In Rotterdam the incidence of syphilis remained almost the same between 1976 and 1985 (28.5 and 24.5 per 100000 respectively). Rotterdam has a different population from Amsterdam, with fewer homosexual men and prostitutes using drugs, which may be why neither the sudden rise nor the subsequent fall in the incidence of syphilis seen in Amsterdam was seen in Rotterdam.

In conclusion, we have evidence that our special surveillance programmes appreciably influenced the decline of the incidence of syphilis in Amsterdam in 1981-3, and that fear of AIDS caused a further decline from 1984 onwards.

TABLE IV Rectal and homosexually acquired gonorrhoea diagnosed in men attending two STD clinics in Amsterdam, 1981-5

\begin{tabular}{llll}
\hline & \multicolumn{3}{l}{ No of men with gonorrhoea } \\
\cline { 2 - 4 } Year & Total & Rectal (\%) & $\begin{array}{l}\text { Homosexually } \\
\text { acquired (\%) }\end{array}$ \\
\hline 1981 & 3407 & $451(13 \cdot 2)$ & $1060(31 \cdot 1)$ \\
1982 & 3139 & $502(16 \cdot 0)$ & $1137(36 \cdot 2)$ \\
1983 & 2837 & $471(16 \cdot 6)$ & $1013(35 \cdot 7)$ \\
1984 & 2380 & $271(11 \cdot 4)$ & $570(23 \cdot 9)$ \\
1985 & 2051 & $218(10 \cdot 6)$ & $435(21 \cdot 2)$ \\
\hline
\end{tabular}


We thank Mrs W Maruanaya for preparing the manuscript, Mrs G Hodge-Manos for supervising the English, and A J Rijsdijk for statistical advice.

\section{References}

1. Hoek JAR van den, Schoonhoven FJ, Arnhem $O$ van, Coutinho RA. Seksueel overdraagbare aandoeningen bij aan heroine verslaafde prostitué(e)s in Amsterdam, 1981. Ned Tüdschr Geneeskd 1984;128:272-4.

2. Bleeker A, Coutinho RA, Bakker-Kok J, Tio D, Koning GAJ de. Prevalence of syphilis and hepatitis $B$ among homosexual men in two saunas in Amsterdam. British Journal of Venereal Diseases 1981;47:196-9.

3. Lumey LH, Kok J, Coutinho RA. Screening for syphilis among homosexual men in bars and saunas in Amsterdam. British Journal of Venereal Diseases 1982;58:402-4.

4. Coutinho RA, Schoonhoven FJ, Ansink-Schipper MC, et al. De verspreiding van penicillinase vormende gonokokken in Amsterdam. Ned Tïdschr Geneeskd 1982;126:221-3.

5. Curran JW, Morgan WM, Hardy AM, et al. The epidemiology of AIDS: current status and future prospects. Science 1985; 229:1352-7.

6. Anonymous. Declining rates of rectal and pharyngeal gonorrhea among males - New York City. MMWR 1984; 33:295-7. 